\title{
The scourge of managerialism and the Royal Australasian College of Physicians
}

\section{The managerialist organisational model has penetrated deeply into our institutions, with destructive consequences}

$\mathrm{M}$ any health practitioners will consider the theory of business management to be of obscure relevance to clinical practice. They might therefore be surprised to learn that the changes that have occurred in this discipline over recent years have driven a fundamental revolution that has already transformed their daily lives, arguably in perverse and harmful ways. They might also be interested to discover that these changes have by and large been introduced insidiously, with little public debate, under the guise of unquestioned "best practice".

This article provides a brief overview of recent management theory and practice and of their farreaching effects in the health and educational sectors. It also provides a more detailed case study of the application of managerialist principles to the Royal Australasian College of Physicians (RACP), both to illustrate how such changes are brought about in practice and to pose the question of the possibility of remedial strategies.

\section{Managerialism}

"Management" refers to the people who organise and control the operations of an enterprise. While there always has to be some kind of management process, its nature and functions have changed radically over time. The traditional control by business owners in Europe and North America gave way during the 19th century to corporate control of companies. This led to the emergence of a new group of professionals whose job it was to perform the administrative tasks of production. ${ }^{1,2}$ Consequently, management became identified as both a skill and a profession in its own right, requiring specific training and based on numerous emergent theories of practice. ${ }^{3}$ The early 20th century saw an emphasis on the scientific organisation of the production process. ${ }^{4,5}$ Still later, the problem became how to ensure that the interests of managers did not conflict with those of the owners of capital..$^{6-8}$

Among these many vicissitudes, a decisive new departure occurred with the advent of what became known as neoliberalism in the 1980s (sometimes called Thatcherism because of its enthusiastic adoption by the Conservative government of Margaret Thatcher in the United Kingdom). ${ }^{9}$ A reaction against Keynesian economic policy and the welfare state, this harshly reinstated the regulatory role of the market in all

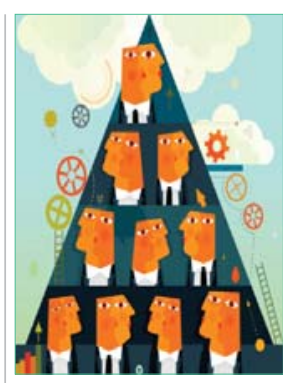

Paul A Komesaroff MBBS, PhD, FRACP1,2

lan H Kerridge MPhil, FRACP, FRCPA ${ }^{3}$

David Isaacs MD, FRACP, FRCPCH 4.5

Peter M Brooks $M D, F R A C P$, FAFRM $^{6}$

1 Monash University, Melbourne, VIC.

2 Centre for Ethics in Medicine and Society, Melbourne, VIC.

3 Centre for Values, Ethics and the Law in Medicine, University of Sydney, Sydney, NSW.

4 The Children's Hospital at Westmead, Sydney, NSW.

5 University of Sydney, Sydney, NSW.

6 Centre for Health Policy, University of Melbourne, Melbourne, VIC.

Paul.Komesaroff@ monash.edu

doi: 10.5694/mjal5.00170

aspects of economic activity ${ }^{10}$ and led directly to the generalisation of the standards and practices of management from the private to the public sectors. The radical cost cutting and privatisation of social services that followed the adoption of neoliberal principles became a public policy strategy rigorously embraced by governments around the world, including successive Liberal and Labor governments in Australia. ${ }^{11}$

The particular system of beliefs and practices defining the roles and powers of managers in our present context is what is referred to as managerialism. ${ }^{12}$ This is defined by two basic tenets: (i) that all social organisations must conform to a single structure; and (ii) that the sole regulatory principle is the market. Both ideas have far-reaching implications. The claim that every organisation - whether it is a mining company, a hospital, a school, a professional association or a charity - must be structured according to a single model, conforming to a single set of legislative requirements, not so long ago would have seemed bizarre, but is now largely taken for granted. The principle of the market has become the solitary, or dominant, criterion for decision making, and other criteria, such as loyalty, trust, care and a commitment to critical reflection, have become displaced and devalued. Indeed, the latter are viewed as quaint anachronisms with less importance and meaning than formal procedures or standards that can be readily linked to key performance indicators, budget end points, efficiency markers and externally imposed targets.

Originally conceived as a strategy to manage large and increasingly complex organisations, in the contemporary world, no aspect of social life is now considered to be exempt from managerialist principles and practices. Policies and practices have become highly standardised, emphasising marketstyle incentives, devolved budgets and outsourcing, replacement of centralised budgeting with departmentalised user-pays systems, casualisation of labour, and an increasingly hierarchical approach to every aspect of institutional and social organisation. In the workplace, the authority of management is intensified, and behaviour that previously might have been regarded as bullying becomes accepted good practice. The autonomous discretion of the professional is undermined, and cuts in staff and increases in caseload occur without democratic consultation of staff. ${ }^{13}$ Loyal long-term staff are dismissed and often humiliated, and rigorous monitoring of the performance of the remaining employees focuses on narrowly defined criteria relating to attainment of financial targets, efficiency and effectiveness. ${ }^{14}$ 


\section{Effects on the health and educational sectors}

The principles of managerialist theory have been applied equally to the public and the private sectors. In the health sector, it has precipitated a shift in power from clinicians to managers and a change in emphasis from a commitment to patient care to a primary concern with budgetary efficiency. ${ }^{15}$ Increasingly, public hospital funding is tied to reductions in bed stays and other formal criteria, and all decision making is subject to review relating to time and money. Older and chronically ill people become seen not as subjects of compassion, care and respect but as potential financial burdens. ${ }^{16}$ This does not mean that the system is not still staffed by skilled clinicians committed to caring for the sick and needy; it is rather that it has become increasingly harder for these professionals to do their jobs as they would like.

In the university sector, the story is much the same; all activities are assessed in relation to the prosperity of the institution as a business enterprise rather than as a social one. ${ }^{17,18}$ Education is seen as a commodity like any other, with priority given to vocational skills rather than intellectual values. Teaching and research become subordinated to administration, top-down management and obsessively applied management procedures. Researchers are required to generate external funding to support their salaries, to focus on short-term problems, with the principal purpose being to enhance the university's research ranking. ${ }^{19}$ The focus shifts from knowledge to grant income, from ideas to publications, from speculation to conformity, from collegiality to property, and from academic freedom to control. Rigid hierarchies are created from heads of school to deans of faculties and so on. Academic staff - once encouraged to engage in public life - are forbidden to speak publicly without permission from their managers. ${ }^{20}$

\section{Case study: the RACP}

The shift from values to organisational efficiency, from leadership to power, and the consequences it brings with it, is likely to be familiar to most readers. The managerialist model has penetrated deeply into our institutions, including both large commercial enterprises and smaller organisations and associations.

The case of the RACP provides a useful illustration of the consequences of the transition from traditional organisational forms to the demands of managerialism. Like many other professional organisations, the College was established primarily to provide a site for members to come together to support each other, to build a community of scholarship, and to contribute to improving the health and wellbeing of the Australian community. The organisation began as a branch of the Royal College of Physicians, which had been formed in London in 1518 under a Royal Charter from Henry VIII. ${ }^{21}$ In 1938, physicians in Australia and New Zealand established their own society, the constitution of which states clearly that its objects are to "bring together physicians for their common benefit and for scientific discussions", "promote the highest quality medical care and patient safety", "maintain professional standards and ethics", develop and advocate health and social policy, and "support and develop physicians as clinicians, public health practitioners, teachers and researchers". ${ }^{22}$

In response to a perception that more efficient and "modern" managerial practices had become necessary, since 2007 the RACP has undergone a series of changes - referred to internally as "corporatisation" - that have largely mirrored those described above in relation to hospitals and universities. The traditional Council was replaced by a Board. Activities and functions of the College became increasingly centralised. Democratic involvement of physicians was replaced by administrative functions carried out by paid managers. Expert advisory groups (EAGs) and other physician-led committees (including for ethics, therapeutics, and the history of medicine) were abolished without meaningful consultation with members. All board and administration activities were now characterised by extreme secrecy and "commercial in confidence", including declarations and management of dualities and conflicts of interests. The salaries of officials were no longer disclosed to members. The intensified authoritarian culture disrupted and undermined staff morale, with staff turnover rates reaching $40 \%$ per year (personal communication from a senior College official).

Risk aversion came to characterise public positions on contentious topics, with a withdrawal from controversial debates on major issues of public interest - such as relationships with industry, endof-life issues, and Indigenous health - and a focus on risk-free administrative matters. Affairs came to a head in late 2013 with a constitutional vote seeking to eliminate altogether the representative nature of the board, reduce its size, and introduce a "nominations committee", by which present officials could decide who could stand for election against them. A commercial publicity company was engaged to influence members' votes and attempts by opponents of the campaign to circulate their objections were strenuously resisted.

As if this was not enough, when a group of more than 120 members exercised their right under the constitution to call for a vote by members on introducing a requirement for transparency and accountability, action was initiated in the Federal Court to prevent such a vote being taken, with the Board actually arguing to the court that "it is no part of the function of the members of a company to express an opinion ... about how the power vested ... in the directors ought to be exercised by them" (RACP submission to the Federal Court, NSD 119 of 2014, 11 February 2014). The pursuit of RACP members through the courts was divisive and expensive - with 
legal costs estimated to be in the order of $\$ 100000$ although the exact figures, like the CEO's salary and the costs of the failed referendum, have never been disclosed to members.

The loss of the constitutional vote did not, however, lead to a change in direction. The culture of secrecy and dogged commitment to corporate principles persisted, increasing further the sense of disenchantment and disengagement among members. This was reflected in the voting turnout for the 2014 Presidential ballot of a historically low level of about $6 \%$ and in the College's approach to this ballot where, contrary to democratic principles long established in Australia, the voting figures were kept secret and only the identity of the winner was revealed to members (correspondence from RACP Company Secretary, 22 April 2014).

Responding to the mounting crisis, expensive "consultant" reports were commissioned to determine whether the decision to abolish the ethics committee was appropriate (which found that it wasn't) (Blackmer J. Medical ethics at the RACP: where to from here? 20 June 2014) and to assess the views of the members on "board reform" (which showed that they were hostile and disaffected) (Costello K. Report on outcomes from member consultations, 4 August 2014). Indeed, these reports only demonstrated the depth of the hostility of the members towards the College hierarchy, evoking multiple comments about poor communication, disengagement and lack of transparency. We estimate that altogether more than half a million dollars of members' money has been spent on these activities.

While the idea of a nominations committee appears to have been abandoned, the previous CEO has resigned and an ethics committee is to be (re)established (albeit heavily controlled by the Board), it is arguable that little has changed. The official focus of reform continues to be on the size of the Board, while calls for greater transparency and the reintroduction of democratic principles of accountability have been ignored. Not surprisingly, levels of disenchantment continue to rise, with key groups within the College now actively discussing the steps needed to secede from it.

\section{Conclusions: is it possible to reverse the scourge of managerialism?}

The story of the RACP is, sadly, not an isolated one. The adoption of the managerialist model — no doubt initiated in good faith - has transformed an important organisation with a strong democratic tradition into an enterprise that is largely disconnected from its original purpose to "bring together physicians for their common benefit and for scientific discussions".
Consistent with the experience in other settings, including hospitals and universities, the managerialist transformation of the organisation has led to a fundamental redirection of its values and purposes, with few if any beneficial outcomes. ${ }^{23}$ The transition of the RACP from a cooperative association to a commercial enterprise run by professional managers epitomises how deeply the new organisational forms have cut into Australian society. The widespread adoption of managerialist principles and practices has led not to greater efficiency and effectiveness but to a loss of cultural depth and communal values.

Is it too late to change? Can the trends be reversed? Can valued institutions be restored to their original purposes? Although it is not possible to answer these questions with confidence, at least in the case of the RACP it is possible to say what the conditions of such a process of restoration would entail. To survive, the College must return to its original mission of providing a forum for physicians to communicate with each other. Secrecy and lack of accountability have to be overcome. An investigation into what has gone wrong is needed, leading to reforms designed to ensure re-engagement of members. The democratic, physician-led committees will need to be reinstated. Transparency of the processes for managing dualities and conflicts of interest within the College will have to be reintroduced. Respect for contrary views expressed by Fellows and trainees, individuals and groups must be re-established.

Whether these changes are possible cannot yet be determined. Whether the damage done to the larger institutions - the public hospitals and the universities - can be reversed, or even stemmed, is a bigger question still. The most that can be said is that even if the present, damaging phase of managerial theory and practice eventually passes, its destructive effects will linger on for many years to come.

Competing interests: We are Fellows of the RACP and all have held honorary positions within it over a number of years. Paul Komesaroff was chair of the RACP Ethics EAG and its forerunners from 1995 until it was disbanded by the College in 2013, and was a member of the Therapeutics EAG, the Policy and Advocacy Committee and many other committees. Ian Kerridge was a member of the Ethics EAG from 2008 to 2013. David Isaacs is Editor-in-Chief of the Journal of Paediatrics and Child Health, a former chair of the Written Examination Committee, and a member of the disbanded Ethics EAG. Peter Brooks was a member of the College Council from 1985 to 1995, Honorary Secretary from 1990 to 1995, chair of the Workforce EAG until its disbandment in 2011, a former chair of the Research Advisory Committee and the Fellowships Board, and a member of many other committees over a 30-year period. Paul Komesaroff was chair and David Isaacs and lan Kerridge were members of the working group that prepared the guidelines for interaction with industry (awaiting ratification) between 2011 and 2014. We all advocated for a "No" vote in the constitutional referendum of 2013 , were signatories to a call for greater transparency and democracy in the College, and were subject to legal action in the Federal Court by the College. Paul Komesaroff teaches ethics at Monash University, and lan Kerridge and David Isaacs teach ethics at the University of Sydney.

Provenance: Not commissioned; externally peer reviewed.

References are available online at www.mja.com.au. 
1 Durkheim E. The division of labor in society. New York: Free Press, 1964.

2 Weber M. Economy and society. New York: Bedminster Press, 1968.

3 Enteman WF. Managerialism: the emergence of a new ideology. Madison: University of Wisconsin Press, 1993.

4 Taylor FW. The principles of scientific management. New York and London: Harper \& Brothers, 1911.

5 Mayo E. The human problems of an industrial civilization. London: Routledge, 2010.

6 Burnham J. The managerial revolution: what is happening in the world. New York: John Day Company, 1941.

7 Drucker PF. The concept of the corporation. New York: John Day Company, 1946.

8 Whyte WH. The organization man. Philadelphia: University of Pennsylvania Press, 2002.

9 Hayek FA. The constitution of liberty. Chicago: University of Chicago Press, 1960.

10 Vinen R. Thatcher's Britain: the politics and social upheaval of the Thatcher era. London: Pocket Books, 2009.

1 Beeson M, Firth A. Neoliberalism as a political rationality: Australian public policy since the 1980s. J Sociol 1998; 34: 215-231.

12 Cunliffe AL. A very short, fairly interesting and reasonably cheap book about management. London: Sage Publications, 2009.

13 Enteman WF. Managerialism: the emergence of a new ideology. Madison: University of Wisconsin Press, 1993.

14 Simmons J. Managing in the post-managerialist era: towards socially responsible corporate governance. Management Decision 2004; 42: 601-611.

15 Alvesson M, Willmott $\mathrm{H}$, editors. Critical management studies. London: Sage Publications, 1992.

16 Hitchcock K. Dear life: on caring for the elderly. Quarterly Essay 2015; 57; Mar.

17 Pollitt C. Managerialism and the public services: the AngloAmerican experience. Oxford: Blackwell, 1993.

18 Preston DS. Managerialism and the post-enlightenment crisis of the British university. Educational Philosophy and Theory 2001; 33: 343-363.

19 Saunders M. The madness and malady of managerialism. Quadrant 2006: Mar: 9-17.

20 Deem R, Brehony KJ. Management as ideology: the case of "new managerialism" in higher education. Oxford Review of Education 2005; 31: 217-235.

21 Clark GC. History of the Royal College of Physicians of London. Br Med J 1965; 1: 79-82.

22 Royal Australasian College of Physicians. RACP governance. http://www.racp.edu.au/page/racp-governance (accessed Feb 2015).

23 Klikauer T. Managerialism: critique of an ideology. Basingstoke: Palgrave Macmillan, 2013. 
This inserted article to the Medical Journal of Australia is a response by the Royal Australasian College of Physicians (RACP) to an article in this issue of the Journal: Komesaroff PA, Kerridge IA, Isaacs D, Brooks PM. The scourge of managerialism and the Royal Australasian College of Physicians. Med J Aust 2015; 202: 519-521. The RACP was made aware only recently of the article, which was submitted to the Journal some time ago. Due to this unique circumstance, a rapid and simultaneous response to the article is provided in this issue of the MJA, and this has delayed distribution of the issue. We apologise for the delay. Publication of this insert should not be taken as creating a precedent at the MJA.

Editorial Advisory Committee: Charles Guest MPH, PhD, FAFPHM

\section{The Royal Australasian College of Physicians: a 21st century college}

\section{A statement from the Royal Australasian College of Physicians}

O

ne of the great lessons of the 20th century was the danger of ideologies that attempted to squeeze the complexity of the world into their frameworks.

The authors of "The scourge of managerialism and the Royal Australasian College of Physicians ${ }^{\prime 11}$ have fallen into this trap by attempting to portray as a "corporatisation" framework a series of structural changes being undertaken to make the Royal Australasian College of Physicians (RACP) more focused on the needs of its members.

Komesaroff and colleagues argue that the College is victim to a takeover from a faceless class of managers and technocrats. Proposals for a more streamlined Board and a College Council that bring our disparate specialties together are characterised as markers on the road to a neoliberal dystopia.

The fundamental flaw in the article is that it provides little attention to facts that do not fit in with its argument. In portraying the College's role as "providing a forum for physicians to communicate with each other", it largely overlooks the objectives of the College that demand it be and remain an outwardlooking institution committed to maintaining the highest professional standards, delivering robust training to its 6000 trainees and publicly advocating for the health of the public.

How does the authors' analysis that the College has been captured by faceless managers account for the Australian Medical Council's recent decision to award the College 6 years' accreditation as the sole trainee of specialist physicians in Australia and New Zealand? Why would these supposed disciples of Thatcher and Reagan be allowing such a progressive advocacy agenda? At our recent Congress, the RACP adopted a progressive and controversial policy on asylum seekers; embraced the complexity of medicinal marijuana and end-of-life care; and grappled with confronting issues like gender identity and Indigenous health. The Board recently voted to divest investments identified as being directly and materially involved in fossil fuel activities.

And how does an analysis about managerial control account for the many Fellow committees that directly shape the College, or the current proposal to create an influential and representative College Council that will provide a forum to bring together our disparate specialties to share insights, collaborate and drive our broader agenda? The article's portrayal of reforms championed by the Board needs to be challenged. While a minority resisted the constitutional changes proposed in 2013, a two-thirds majority supported the proposals.

These facts are paid little attention because they get in the way of what appears to be an ideological critique of the College, its Board and its dedicated and professional staff.

The reality is that this College, far from embracing "corporatism", is following the lead of member-based non-for-profit associations around the world and rethinking the way it is run - focusing on the needs of our members, especially those entering the profession, harnessing technology, reviewing our committees and services to ensure they remain relevant. We cannot work to a collective vision if we do not empower a democratically elected Board to set a strategy and implement it. Change upsets people, but the risk of not changing is that an organisation will become irrelevant because of pressing external challenges.

If the College were to be accused of pursuing any ideological theory or agenda it would be that of "empowerment". Empowerment is how we engage our more than 22000 members to train the next generation of physicians, nurture their careers and make a difference as leaders in our communities. That may not be as dramatic a story as a sinister corporate takeover of the College, but it's one that the College believes in for the benefit of our current and future Fellows and trainees, and for the communities they serve. 
1 Komesaroff PA, Kerridge IA, Isaacs D, Brooks PM. The scourge of managerialism and the Royal Australasian College of Physicians. Med J Aust 2015; 202: 519-521. 